\title{
Chemical and biological properties of anti-wrinkle peptide Argireline
}

\author{
Argirelina - peptyd przeciuzmarszczkowy. \\ Wlaściuości chemiczne i biologiczne
}

\begin{abstract}
Argireline, a peptide with the sequence: Ac-Glu-Glu-MetGln-Arg-Arg- $\mathrm{NH}_{2}$, also known as Acetyl Hexapeptide-8, reduces facial lines and wrinkles by destabilization of the formation of the SNARE complex (SNAP Receptor, soluble $N$ ethylmaleimide sensitive factor (NSF) attachment protein receptor), thus preventing muscle contraction. It is a biosafe cosmetic alternative to the botulinum toxin. The method of choice in bioactive peptide analysis is reversed-phase high performance liquid chromatography coupled with mass spectrometry (LC-MS).

The aim of this work was to present the properties of Argireline and the analysis of cosmetic products containing this peptide.

Previous reports on possible Argireline transformations in cosmetic formulations have not confirmed deacetylation, whereas the oxidation of methionine residue was detected by our team. As the biological activity of the oxidized Argireline is not known, further biological studies, as well as efficient analytical procedures for transformation monitoring and quality control in cosmetic products, are necessary.
\end{abstract}

Keywords: Argireline, anti-wrinkle activity, LC-MS, methionine oxidation

\section{STRESZCZENIE}

Argirelina, peptyd o sekwencji: Ac-Glu-Glu-Met-Gln-Arg-Arg- $\mathrm{NH}_{2}$, znana także pod nazwą acetyloheksapeptyd-8, redukuje zmarszczki mimiczne poprzez destabilizację powstawania synaptycznego kompleksu SNARE (receptor SNAP, receptor białka wiążącego czynnik wrażliwy na $\mathrm{N}$-etylomaleimid), co zapobiega skurczom mięśni. Argirelina jest więc bezpieczną alternatywą dla Botoksu. Najczęściej wykorzystywaną metodą badania bioaktywnych peptydów jest wysokosprawna chromatografia cieczowa w odwróconym układzie faz, sprzężona ze spektrometrią mas (LC-MS).

Celem pracy było przedstawienie właściwości Argireliny oraz wyników wykrywania tego peptydu w produktach kosmetycznych.

Badania stabilności Argireliny w produktach kosmetycznych nie wykazały deacetylacji jednak udało się wykryć utlenienie atomu siarki w reszcie metioniny. Nie jest znana aktywność biologiczna utlenionej Argireliny, co sugeruje potrzebę przeprowadzenia badań biologicznych oraz opracowania skutecznych metod monitorowania składu produktów kosmetycznych.

Słowa kluczowe: Argirelina, efekt przeciwzmarszczkowy, LC-MS, utlenienie metioniny

\section{INTRODUCTION}

A significant part of society recognizes a youthful, aesthetically appealing face as a sign of health and prosperity. The methods to fulfill the dream range from facial surgery, Bot- ulinum toxin and dermal filler injections to the topical cosmetics application [1-3]. The procedure of choice depends on age, preferences and finances, with the level of invasiveness being one of the significant factors. 

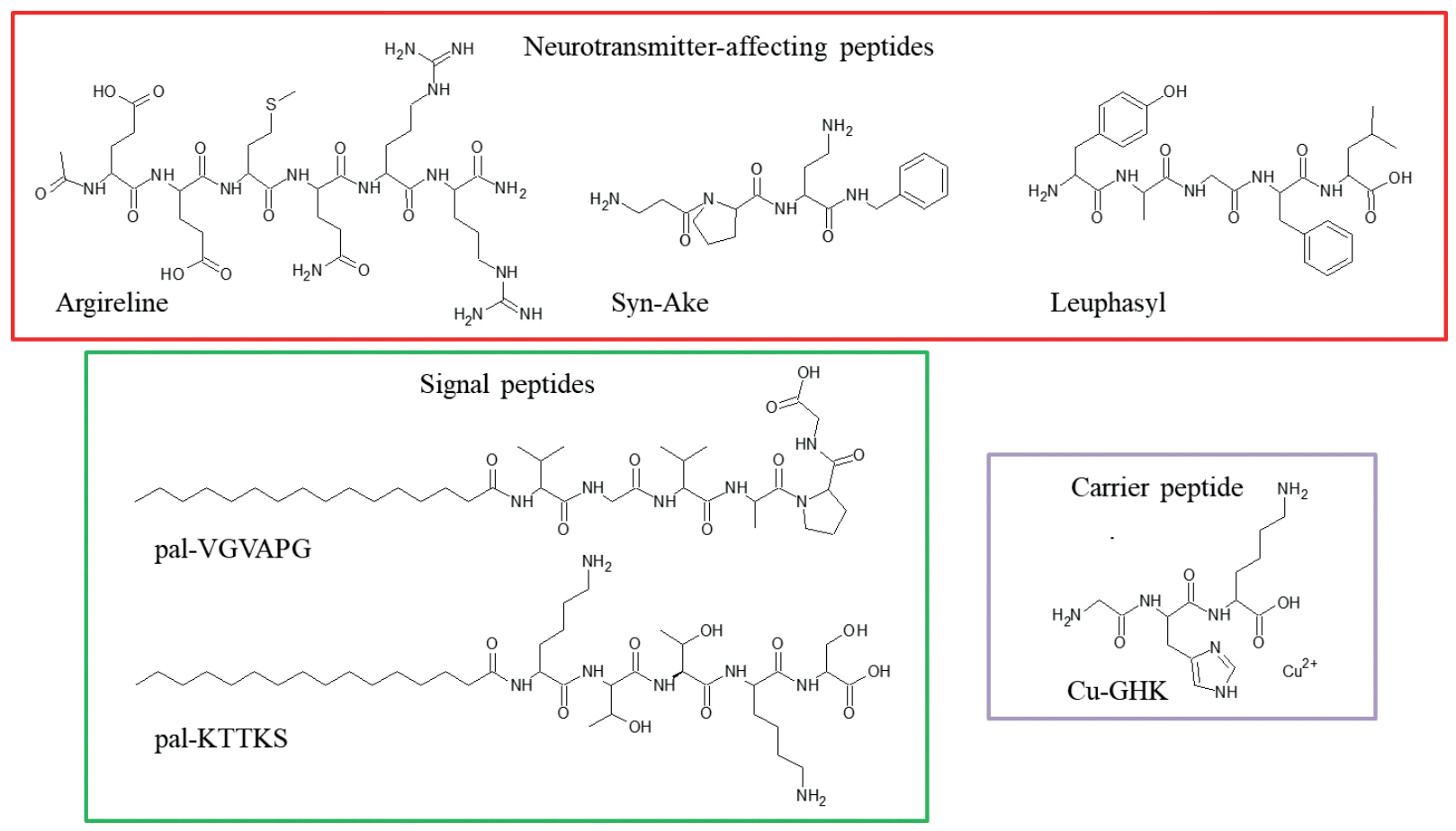

Fig. 1 Selected examples of cosmeceutical peptides

Source: Based on $[5,7]$

Cosmeceuticals are defined as cosmetic products applied topically (creams, lotions, serums, and ointments), specially designed to improve the appearance of aging skin. They are usually not tested nor approved as drugs that alter cellular functions, but rather appear in the consumer arena based on theoretical benefits from in vitro studies of active ingredients. Specific regulations based on concentration of discussed components and activity claims differ among countries and organizations.

Peptides, short sequences of amino acids, have a broad range of biological functions and are a rapidly expanding category of cosmeceuticals with growing evidence supporting their beneficial use in the treatment of aging skin [4]. Peptides are important in many natural processes relevant to skincare, such as the modulation of cell proliferation, inflammation, cell migration, melanogenesis, angiogenesis, and protein synthesis and regulation. In the United States alone there are more than 25 different peptides routinely applied in various skincare products and many more are under development by cosmetic companies worldwide. Several excellent review articles are available describing peptides used in cosmeceuticals [5-10]. Cosmeceutical peptides are usually categorized into three groups: signal peptides, neurotransmitter-affecting peptides, and carrier peptides. Fig. 1 presents representative examples of each of these groups.

\section{BIOLOGICAL ACTIVITY OF ARGIRELINE}

The ingredients indicated as responsible for the wrinkle-free effect of cosmeceuticals include agents affecting general skin condition by rehydration, stimulation of collagen production and increase of dermal thickness (for example, retinoic acid, alpha-hydroxy acids, antioxidants, estrogens, and growth factors) whereas selected natural products and peptides (e.g. Argireline) influence muscle tone $[11,12]$.

The activity of Argireline, one of the neurotransmitter-affecting peptides, is similar to botulinum toxin (Botox). Both of them function topically to relax muscles by inhibiting vesicle docking through prevention of the synaptosome-associated protein receptor (SNARE) complex formation [13]. Although properly administered Botox is safe, there are systemic side effects and contraindications that have to be analyzed before treatment [14]. The popularity of Botox is significantly undermined by the fear of the needle, therefore a whole range of "botox-like needle-free" cosmetic products (creams, sera, fillers) has been developed. Their advantages include self-administered topical application, milder effects allowing prolonged use and a lack of side effects.

Argireline is classified as a neurotransmitter which inhibits the release of receptors (e.g. acetylcholine receptor) $[14,15]$. The search for data on Argireline activity and applications is complicated by several names used to describe this peptide [16]. They include formal peptide names: L-Argininamide, $N$-Acetyl-L-Alpha-Glutamyl-L-Alpha-Glutamyl-L-Methionyl-L-Glutaminyl-L-Arginyl- and Acetyl-Glu-GluMet-Gln-Arg-Arg-amide, as well as [616204-22-9] (CAS system), UNII L4EL31FWIL (Global Substance Registration System Unique Ingredient Identifier), acetyl hexapeptide-3 
(WHO-DD) and acetyl hexapeptide-8 (INCI). In this text we use the common name Argireline to describe the peptide, although there is a product offered under this trade name by Lipotec, an aqueous solution containing $0.5 \mathrm{~g} / 1$ of the powder (i.e., 0.05\% aqueous solution; pure active peptide in solution estimated at $\sim 0.56 \mathrm{mM}$ ) [17].

The amino acid sequence of Argireline comes from the $N$-terminal end (residues 1-12) of the synaptosome-associated $25 \mathrm{kDa}$ protein (SNAP-25) protein [14]. Argireline inhibits the formation of the soluble SNARE complex, which is made up of vesicle associated membrane protein (VAMP), syntaxin, and SNAP-25 protein [15, 18]. The SNAP-25 is necessary for the successful release of acetylcholine vesicles (Fig. 2). The SNARE complex is responsible for the fusion of vesicles with the plasma membrane. The result of this process is a $\mathrm{Ca}^{2+}$-dependent neurotransmitter release. Argireline competes with SNAP-25 for a position in the SNARE complex. The destabilization of SNARE complex stops the release of the neurotransmitters by the vesicle, consequently abrogating $\mathrm{Ca}^{2+}$-triggered exocytosis. Then the muscle contraction is attenuated and as a result the muscle is relaxed preventing formation of facial lines and wrinkles [15].

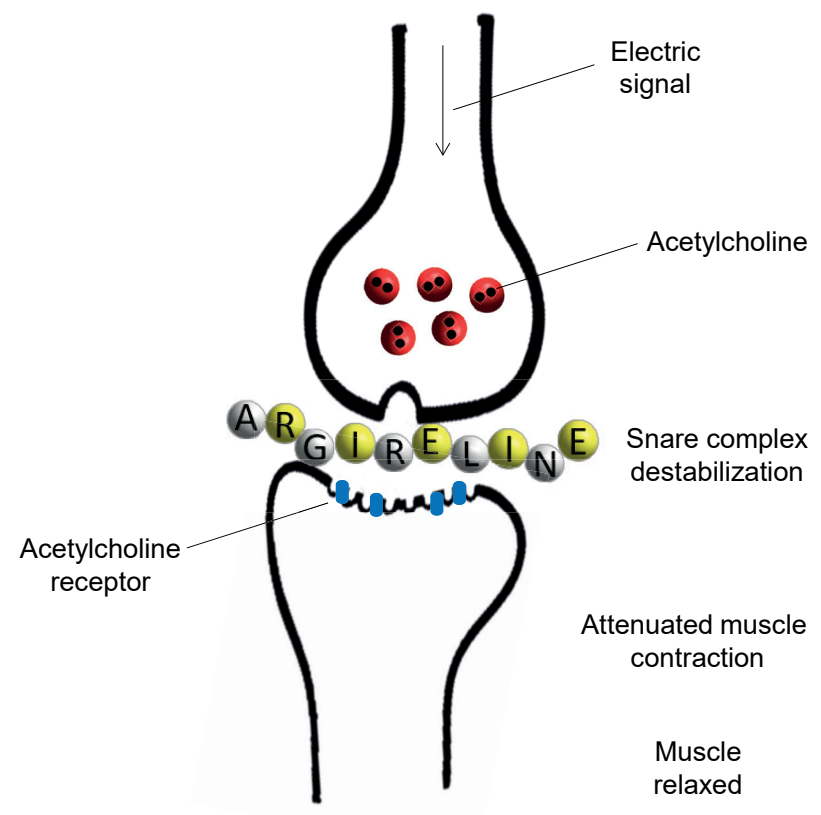

Fig. 2 Schematic representation of Argireline's mode of action Source: Own study, based on [17]

Argireline is a biosafe cosmetic alternative to reduce facial lines and wrinkles [15]. There are many reports confirming the anti-wrinkle effects of Argireline [5, 6, 15, 19, 20]. In one of them 10 women used the oil/water $(\mathrm{O} / \mathrm{W})$ emulsion with $10 \%$ of Argireline twice a day for 30 days. The results of this experiment suggest that the applied product reduces the depth of wrinkles by $30 \%$ [15]. In another study, a $2 \%$ solution of Argireline reduced wrinkles after just one week.
The roughness and depth of wrinkles were also reduced [19]. A $27 \%$ reduction of wrinkles was observed in 10 women after application of a cream with 5\% Argireline twice a day [5]. In the study by Ruiz et al. a group of 20 people tested an emulsion containing Argireline, with a significant reduction of wrinkles ranging between 41.83 and $78.25 \%$ [20].

According to U.S. National Library of Medicine (NLM) at the National Institutes of Health (NIH) Argireline activity was investigated in clinical trials [21]. Two trials were directed at blepharospasm, a focal dystonia affecting primarily the orbicularis oculi muscles. Argireline as a competitive SNAP-25 inhibitor is considered as a replacement for injectable botulinum neurotoxin used regularly in blepharospasm treatment. Although the trial did not provide statistically relevant significance, the safety profile and the trend for improvement suggest that Argireline may find medical application [22].

It is worth knowing that the effect of Argireline on human cell proliferation was studied in several cell lines. The evident antiproliferative effect (67\% inhibition) has been observed at $100 \mu \mathrm{M}(90 \mu \mathrm{g} / \mathrm{ml})$ concentration, whereas at a lower concentration no difference between Argireline and the control was observed. The cytotoxic activity against human skin fibroblasts was also detected only for relatively high concentrations after prolonged exposure [23].

There are also reports on trials directed at the application of topical Argireline in the treatment of periorbital wrinkles and cosmetic appearance of oily skin, as well as the wrinkle reduction potential of a novel compounded skincare cream, containing, among other components, Argireline. The latest trial, conducted by Wayne State University, Michigan, U.S., is to be completed in 2021 [21]. A thorough report on Argireline activities was published by the Expert Panel for Cosmetic Ingredient Safety [34].

\section{SKIN PENETRATION}

Active substances contained in cosmetics, e.g. peptides, must be delivered to the skin in a stable form and be capable of producing the desired biological effect in vivo. A significant problem in transdermal deliveries is the barrier of the stratum corneum. Due to the skin barrier, the molecular weight of the peptides used should be less than $500 \mathrm{Da}$, so it is not surprising that the penetration of Argireline molecule (888 Da) into the skin is limited, although it depends on the composition of the formulation applied [23, 24, 28].

Hairless guinea pig skin and human cadaver skin were used in the study of the degree of skin penetration by Argireline. The results of the in vitro experiment showed that the Argireline penetrated into the skin and remained mainly in the stratum corneum (for hairless guinea pig skin it was $0.54 \%$, for human skin $0.22 \%$ of the applied dose). The amount found in the epidermis was similar in both cases (0.01\%). It has not been conclusively confirmed whether 
small amounts penetrating the epidermis are sufficient to cause a physiological effect. In addition, the peptide was not detected in the dermis, and no Argireline metabolites were detected in any of the skin layers, neither in hairless guinea pig nor in human skin studies [26].

Wrinkles appear deep in the dermis, and anti-aging cosmetics often poorly penetrate the stratum corneum, hence their limited activity. Therefore, professional cosmetic treatments support the penetration of cosmetics by using additional methods - iontophoresis, microneedles, sonophoresis, thermal ablation, and radiofrequency ablation [27, 28].

\section{ARGIRELINE ANALOGS - STRUCTURE- -ACTIVITY RELATIONSHIPS}

Structure-activity relationships (SARs) can be used to predict the physicochemical or biological properties of substances. Such information may be helpful in discovering which parts of the molecule are important in biological activity. Unfortunately, there is very little literature describing structure-biological activity study of Argireline. In Fig. 3 Argireline analogs with various modifications are presented.
An example of Argireline derivative is acetyl octapeptide-3 with the sequence: Ac-Glu-Glu-Met-Gln-Arg-ArgAla-Asp- $\mathrm{NH}_{2}$. This peptide is more effective in wrinkle improvement than Argireline [29].

Argireline analogs modified in position 6 of the peptide chain have been the object of investigation of Kraeling and co-workers [26]. In this series of analogs, the Arg residue was replaced by the isotopically labeled amino acid: $\left({ }^{13} \mathrm{C}_{6},{ }^{15} \mathrm{~N}_{4}\right)$ Arg. These compounds were used as internal standards (IS) for quantitation of Argireline in cosmetic products by LC-MS. In our work we used another analog of Argireline: H-Asp-Glu-Met-Gln-Arg-Arg- $\mathrm{NH}_{2}$ as IS to monitor oxidation during sample preparation [30].

To explain the interaction of copper(II) ions with Argireline, three of its derivatives have been described: H-GluAla-Met-Gln-Arg-Arg- $\mathrm{NH}_{2}, \quad$ H-Glu-Ala-His-Gln-Arg-Arg$\mathrm{NH}_{2}$ and H-Glu-Ala-Met-Gln-Ala-Arg-NH $\mathrm{NH}_{2}$ [31]. Among these analogs the most stable copper(II) complex was formed with $\mathrm{H}$-Glu-Ala-His-Gln-Arg-Arg- $\mathrm{NH}_{2}$, in which the nitrogen atom from histidine imidazole is bound to a metal ion. Moreover, this study indicates that the acetylation of


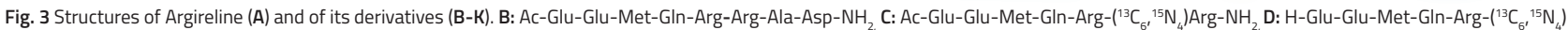
Arg- $\mathrm{NH}_{2}$, E: H-Asp-Glu-Met-Gln-Arg-Arg- $\mathrm{NH}_{2}, \mathrm{~F}: \mathrm{H}$-Glu-Ala-Met-Gln-Arg-Arg-NH ${ }_{2}, \mathrm{G}: \mathrm{H}$-Glu-Ala-Met-Gln-Ala-Arg-NH $\mathrm{H}_{2} \mathrm{H}: \mathrm{H}$-Glu-Ala-His-Gln-Arg-Arg-NH, ${ }_{2}$ : Ac-Glu(OMe)-Glu(OMe)-Met-Gln-

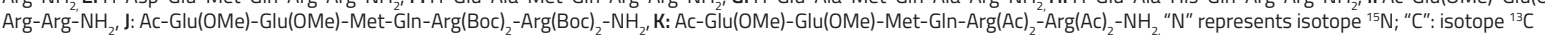

Source: Own study, structures based on sequences presented in: [26, 29, 30-32] 
the $N$-terminal amino group does not affect the structure of the complex formed.

In another study, new analogs of Argireline (Fig. 3, structures I, J, K) were analyzed for their abilities to permeate through skin and reduce winkles [32]. Chemical modification of these compounds was carried out by increasing the lipophilicity and molecular weight of peptides. The results suggest that peptides: Ac-Glu(OMe)-Glu(OMe)-Met-Gln$\operatorname{Arg}(\mathrm{Ac})_{2}-\mathrm{Arg}(\mathrm{Ac})_{2}-\mathrm{NH}_{2}$ and $\mathrm{Ac}-\mathrm{Glu}(\mathrm{OMe})-\mathrm{Glu}(\mathrm{OMe})-\mathrm{Met}-$ Gln-Arg(Boc) $)_{2}-\operatorname{Arg}(\mathrm{Boc})_{2}-\mathrm{NH}_{2}$ may be an alternative for the treatment of wrinkles.

Finally, it should be pointed out that the structure-biological activity studies of Argireline, especially concerning other biological activity, including toxicity, should be continued.

\section{THE CONTENT OF ARGIRELINE IN COSMETIC PRODUCTS}

Although there are numerous cosmetic products containing Argireline, the information on the actual amount of the peptide in the composition is difficult to establish. Among the 354 products reported in the FDA Voluntary Cosmetic Registration Program, the Argireline concentration range is $0.000005-0.005 \%[33,34]$. The regulations require the arranging of major components of cosmetic product according to diminishing content down to $1 \%$, whereas the order of other components depends on the decision of the producer. The examples presented in Table 1 include preparations used in clinical trials, described in patents or declared by producers. The Expert Panel for Cosmetic Ingredient Safety concluded that Argireline (listed in INCI as Acetyl Hexapeptide-8 Amide) is safe in cosmetics at concentrations up to $0.005 \%$ [34].

Table 1 The content of Argireline in selected cosmetic products

\begin{tabular}{|c|c|c|c|}
\hline \multirow[t]{2}{*}{ Product } & \multicolumn{2}{|c|}{ Argireline content } & \multirow[t]{2}{*}{ Reference } \\
\hline & as declared & $\begin{array}{l}\text { in } 100 \mathrm{~g} \\
\text { of the product }\end{array}$ & \\
\hline $\begin{array}{l}\text { HydroGold } 9 \\
\text { (patch) }\end{array}$ & $0.01 \mathrm{mg} / 100 \mathrm{mg}$ & $10 \mathrm{mg}$ & [35] \\
\hline $\begin{array}{l}\text { Argireline Solution } 10 \% \\
\text { (The Ordinary) }\end{array}$ & $10 \% *$ & $5 \mathrm{mg}$ & [36] \\
\hline $\begin{array}{l}\text { Laser Rejuvenation } \\
\text { restoring damage skin } \\
\text { (cream) }\end{array}$ & $0.0001 \mathrm{~mL} / 1 \mathrm{~mL}$ & $* *$ & [37] \\
\hline $\begin{array}{l}\text { Scinic Peptide } \\
\text { Ampoule } 95\end{array}$ & $1 \mathrm{ppm}$ & $0.1 \mathrm{mg}$ & [33] \\
\hline $\begin{array}{l}\text { Patent example } \\
\text { (Compounds which } \\
\text { inhibit neuronal } \\
\text { exocytosis) }\end{array}$ & $0.005 \%$ & $5 \mathrm{mg}$ & [38] \\
\hline
\end{tabular}

Recent recommendations on analysis of cosmetic ingredients do not include methods of peptide determination [39]. The number of scientific reports concerning peptide analysis in cosmetic products is limited. In the case of Argireline, a systematic study based on hydrophilic interaction liquid chromatography with tandem mass spectrometry (HILIC-MS/MS) was conducted [40, 41]. The sample preparation involved extraction of a test portion of a cosmetic product using a mixture of acetonitrile, water, trifluoroacetic acid, and formic acid (85:15:0.1:01, v:v), followed by solid-phase extraction. Internal standards in the form of isotopically labeled peptides (Argireline and its deacetylated analog, Fig. 3, structures C and D, respectively) were used for recovery studies and quantitative analysis. The highest detected concentration was $42.30 \mu \mathrm{g} / \mathrm{g}$, which corresponds to $4.23 \mathrm{mg} / 100 \mathrm{~g}$ and is in the range of concentrations reported in Table 1. It is worth noting that the deacetylated form of Argireline was not detected.

Relatively simple sample preparation procedure was used in Argireline permeability studies, when $0.1 \%$ aqueous formic acid was used to fill the receptor chamber and to extract the strip tapes. The resulting solutions were analyzed by LCMS/MS [28]. Argireline was used as an internal standard in the development of the analytical LC-MS/MS procedure for SNAP-8 peptide (Fig. 3, structure B) determination in biodegradable microneedle patches. The sample preparation consisted of extraction with water and filtration, due to the relatively simple matrix of microneedle load [29].

\section{ARGIRELINE TRANSFORMATIONS - OXIDATION}

So far, deacetylation is the only degradation reaction that has been studied in commercially available Argireline-containing cosmetics [40]. However, there is a methionine residue in Argireline sequence, which is prone to oxidation. It can undergo oxidation under mild conditions, therefore we wanted to analyze if and to what extent it oxidizes during storage [30]. The identification of the oxidized Argireline by mass spectrometry is facilitated by a characteristic neutral loss of $\mathrm{CH}_{3} \mathrm{SOH}$ observed during collision-induced dissociation (CID) (Fig. 4) [42].

Therefore, in our study we tried to develop a simpler and more cost-efficient method for analyzing Argireline and its possible oxidation products without isotopically labelled standards [30]. To perform a quantitative analysis we spiked the samples with a peptide analog of Argireline H-Asp-Glu-Gln-MetArg-Arg- $\mathrm{NH}_{2}$ (Fig. 3, structure E) as an internal standard. The glutamic acid of Argireline was exchanged for aspartic acid in the analog to introduce a mass difference, while retaining similar ionization efficiency. The acetyl group was removed to increase the hydrophilicity of the peptide and thus shorten its re- 

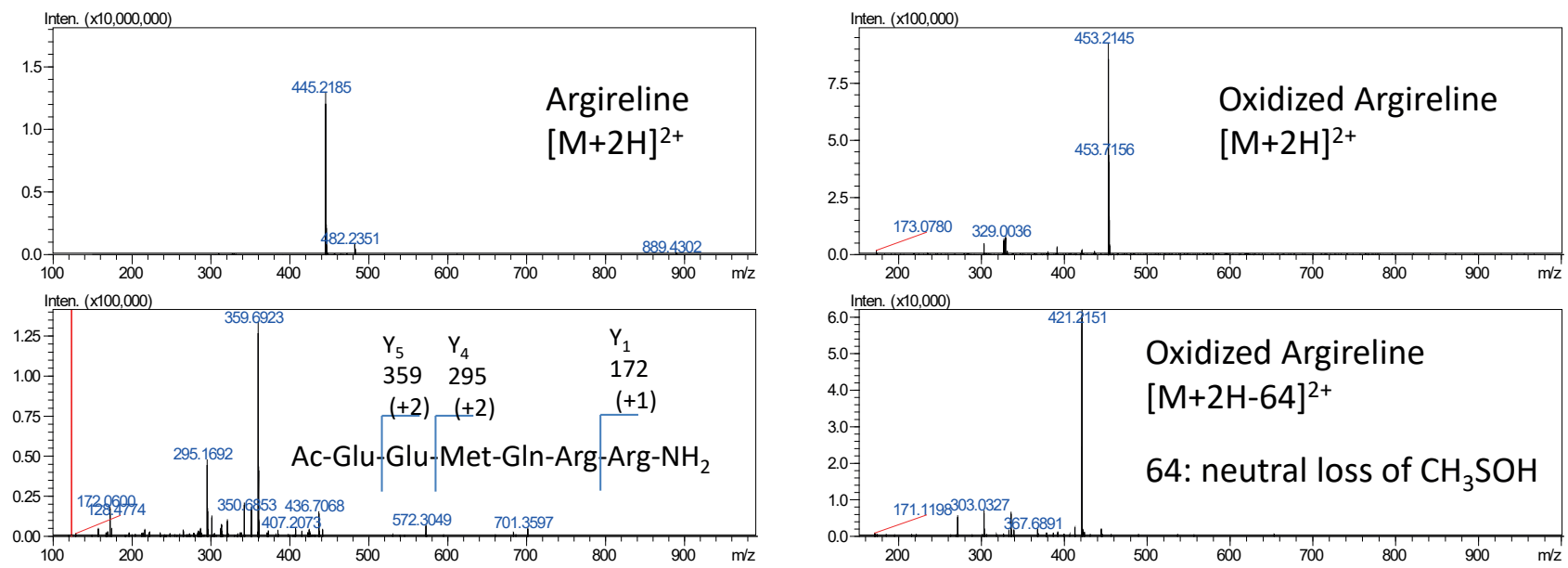

Fig. 4. Mass spectra (top panels) and collision-induced dissociation spectra (bottom panels) of Argireline ( $445.2185 \mathrm{~m} / \mathrm{z}$ ) and its oxidized form (453.2145 $\mathrm{m} / \mathrm{z}$ ) (Shimadzu IT-TOF mass spectrometer) Source: experimental data from authors' research
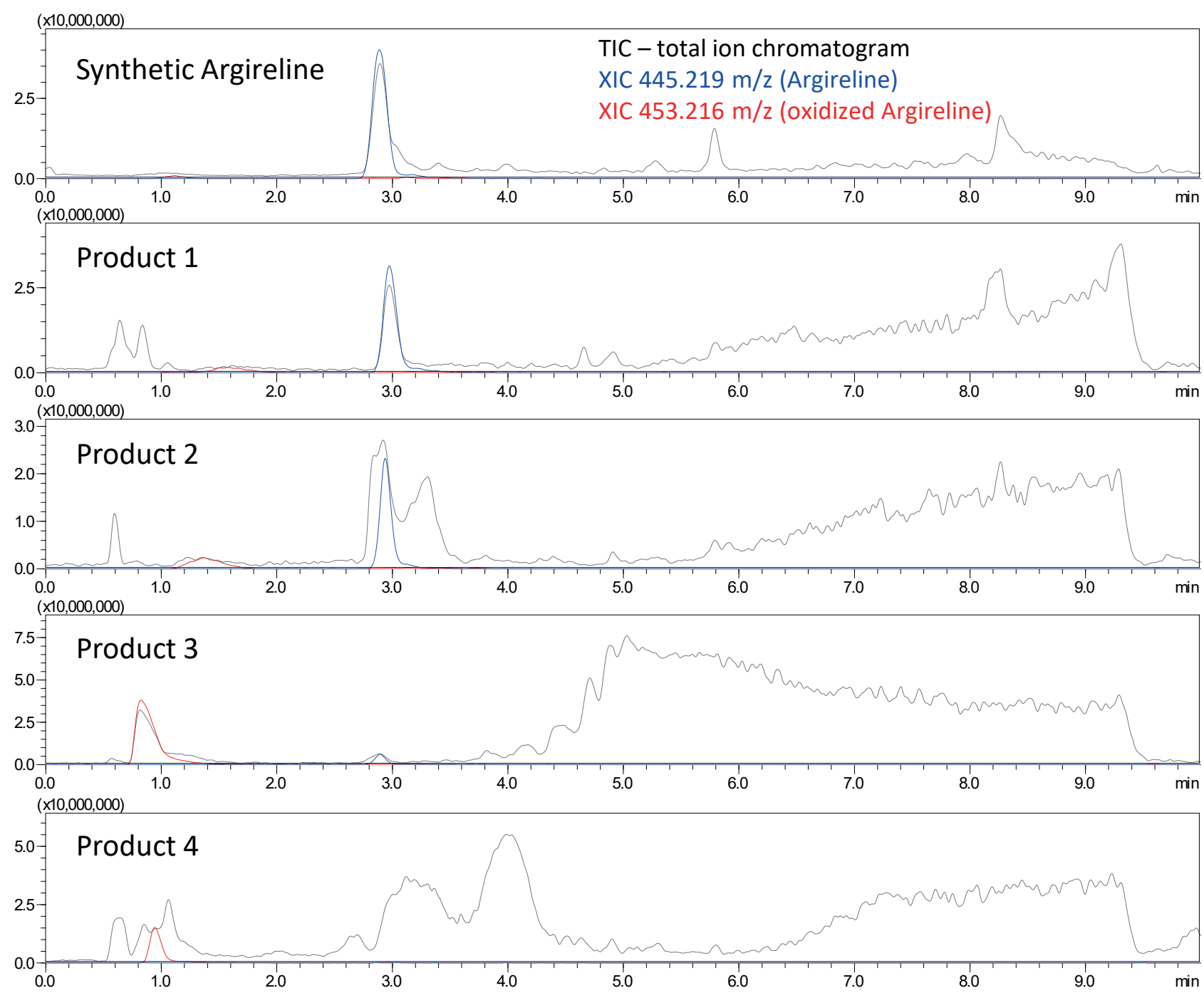

Fig. 5 LC-MS chromatograms of synthetic Argireline (top panel) and selected sera (Products 1-4). Gray line represents total ion current, blue and red lines represent Argireline and oxidized Argireline, respectively (these traces were magnified 3 times for increased visibility).

LC-MS conditions: Shimadzu Nexera and IT-TOF instruments, Aeris Peptide XB-C18 column (50×2.1 mm, $3.6 \mu \mathrm{m}$, Phenomenex), 5-80\% gradient of acetonitrile in water, $0.1 \% \mathrm{HCOOH}$. Detailed procedures are described in [30]

Source: Experimental data from authors' research 
tention time in RP-HPLC. The peptide still contained a methionine residue, and was used as an oxidation probe.

Preparing the sample for analysis by liquid chromatography and mass spectrometry (LC-MS) is a major issue, due to a complex matrix of cosmetic products, which contains many MS-incompatible species, such as fatty acids, emulsifiers and preservatives (Table 2) [30]. Moreover, the formulation of the cosmetics is designed to prevent the dissolution and separation of phases, which makes it difficult to extract peptides from the products. Therefore, we have developed a sample preparation protocol in which an aliquot of the sample was suspended in a mixture of $5 \%$ aqueous trifluoroacetic acid and extracted with $\alpha, \alpha, \alpha$-trifluorotoluene. The mixture was then sonicated for 3 hours and centrifuged to facilitate layer separation. The upper aqueous layer was then collected and lyophilized, and the residue was dissolved in water for LC-MS analysis [30].

Table 2 Key ingredients present in tested cosmetics (in alphabetical order)

\begin{tabular}{|c|l|}
\hline $\begin{array}{c}\text { Cosmetic } \\
\text { product }\end{array}$ & \multicolumn{1}{c|}{ Ingredients } \\
\hline \multirow{5}{*}{ Cream } & $\begin{array}{l}\text { Aqua, Argireline, Butylene Glycol, Butyrospermum Parkii } \\
\text { Butter, C12-15 Alkyl Benzoate, Caprylic/Capric Triglyceri- } \\
\text { de, Caprylyl Glycol, Carbomer, Centella Asiatica Leaf Extract, } \\
\text { Ceramide NG, Cetearyl Alcohol, Chlorhexidine Digluconate } \\
\text { Dextran, Citric Acid, Dimethicone, Dipeptide Diaminobuty- } \\
\text { royl Benzylamide Diacetate, Disodium Oleate, Glycerin, Gly- } \\
\text { cine Soja Oil, Heptapeptide-7, Hydrogenated Lecithin, Hy- } \\
\text { droxypropyl Cyclodextrin, Lactic Acid, Leuconostoc/Radish } \\
\text { Root Ferment Filtrate, Magnesium PCA, N-Prolyl Palmitoyl } \\
\text { Tripeptide-56 Acetate, Oligopeptide-68, Olus Oil, Palmitoyl } \\
\text { Hexapeptide-12, Palmitoyl Tripeptide-1, Palmitoyl Tripepti- } \\
\text { de-38, Palmitoyl Tripeptide-8, Panthenol, Parfum (Fragran- } \\
\text { ce), Peg-10 Phytosterol, Pentylene Glycol, Persea Gratissima } \\
\text { Oil, Phenoxyethanol, Polysorbate 20, Potassium Sorbate, Pro- } \\
\text { panediol, Snail Secretion Filtrate, Sodium Benzoate, Sodium } \\
\text { Citrate, Sodium Lactate, Spilanthes Acmella Flower Extract, } \\
\text { Steareth-20, Tetrapeptide-4, Tocopherol, Tocopheryl Acetate, } \\
\text { Triethanolamine, Undaria Pinnatifida Cell Culture Extract, } \\
\text { Xanthan Gum }\end{array}$ \\
$\begin{array}{l}\text { Aqua, Argireline, Caprylyl Glycol, Ethylhexyl Glycerin, Glyce- } \\
\text { rin, Lecithin, Phenoxyethanol, Ubiquinone }\end{array}$ \\
\hline
\end{tabular}

Source: Analysis based on information presented in supporting information to [30]

Both Argireline and its oxidized form were detected in the LC-MS chromatograms (Fig. 5), as the oxidation produces both a characteristic mass difference in the mass spectra, and a characteristic neutral loss of in CID fragmentation spectra (Fig. 4). Since some oxidation was detected in the reference peptide as a result of the sample preparation protocol, the procedure was modified to minimize this effect. Omitting the sample evaporation step was the key difference and resulted in a negligible oxidation of the internal standard. However, Argireline was still oxidized to a high degree. Depending on the sample, the oxidation was often complete [30]. The process mentioned may be a result of not only the air oxygen but also the presence of some ingre- dients present in the cream formulation playing the role of oxidants.

To prepare a skincare product presenting the desired effect, different substances with determined cosmetic activity are added to the cream or serum formulation, as well as various stabilizers and preservatives (Table 2) [43, 44]. The dynamic development of analytical method makes it possible to quickly identify decomposition products [45, 46]. Detection and characterization of any modification of the amino-acid side chain or backbone level are crucial for both regulatory compliance and the reliability of the cosmeceutical potency assessment. Due to the inherent reactivity of peptides and proteins, various spontaneous chemical changes may occur. The stability of cosmetic formulations containing Argireline was tested by Ruiz and co-workers [20]. It was found that Argireline is stable during storage at 25 ${ }^{\circ} \mathrm{C}$, however, a significant decrease to $59 \%$ and to $41 \%$ was observed after heating for 24 hours at $40^{\circ} \mathrm{C}$ or $60^{\circ} \mathrm{C}$, respectively. These results clearly show that higher temperature is a factor which should be taken into consideration in an effort to improve the stability of an active ingredient during storage and heating if the process of formulation requires such conditions. Thermal or proteolytic stability of peptides are not the only factors that determine the active peptide ingredient stability and activity [47, 48]. Peptides, especially those containing methionine residue may be oxidized. Previously we found that Argireline, due to the presence of methionine residue, undergoes such oxidation, which may be caused by the air oxidation but also by the presence of some ingredients in the cream formulation acting as oxidants [30].

\section{THE PROBLEM OF OXIDATION IN BIOACTIVE PEPTIDES}

The analytical characterization of some bioactive peptides has revealed the presence of contaminants that mainly arise from oxidation- and elimination-prone amino acid side chains. Oxidation processes may occur during production, purification, and storage, leading to the conversion of oxidation-prone residues to the corresponding oxidized species, and to substantial alteration of biological activity [49]. Among the 20 natural amino acids, the sulfur-containing Met and Cys, as well as the aromatic His, Trp, Tyr, and Phe contain the most oxidation-prone side chains [50]. Methionine (Met) oxidation in different biotherapeutics has been detected and quantified by applying LC-MS analysis [51]. Met oxidation to sulfoxides or sulfones has been correlated with several adverse effects, including loss of function, decrease of stability or increase in aggregation tendency. Oxidation of Met8 in parathyroid hormone (PTH) causes a large suppression of the hormone activity and may also result in the specific hydrolysis of the peptide bond between Met8 and His9 [52, 53]. In case of cyclolinopeptides, 
Met oxidation is responsible for the development of the bitter off-taste in stored flaxseed oil [54]. The oxidative degradation of methionine containing cyclolinopeptides may be related to the initial amounts of dissolved oxygen in the oil. According to Przybylski and Eskin the usual content of dissolved oxygen in edible oil is sufficient to provide a peroxide value of $10 \mathrm{meq} / \mathrm{kg}$ [55]. Many other examples of the influence of oxidation on biological activity of peptides and proteins are described in recent reviews [14, 49, 56].

\section{CONCLUSIONS}

Argireline (also known as Acetyl Hexapeptide-8) is a biosafe cosmetic alternative to botulinum toxin which reduces facial lines and wrinkles. Using an anti-wrinkle cream is a potentially less invasive, but short-term alternative to other non-invasive treatments such as chemical peels or laser treatments. The only downside to these topical remedies is that they must be used daily. There are many reports confirming the anti-wrinkle effects of Argireline. This peptide is safe in cosmetics at concentrations up to $0.005 \%$. Higher concentrations and prolonged use of Argireline require further studies to ascertain its safety. The stability of Argireline in cosmetic formulation was studied. Whereas the deacetylated form was not detected, we managed to identify the oxidized form of this peptide in creams and sera by LC-MS. Due to the presence of methionine residue, Argireline may undergo such oxidation, caused by the air or by some ingredients in the cream formulation acting as oxidants.

The biological activity of the oxidized Argireline has never been studied, therefore its impact on the effect of cosmeceuticals is unknown. This highlights the need to develop efficient analytical procedures for transformation monitoring and quality control in cosmetic products.

\section{ACKNOWLEDGEMENTS}

The authors would like to thank Andrzej Reszka (ShimPol, Poland) for providing access to LCMS-IT-TOF instrument.

\section{REFERENCES / LITERATURE}

1. Berbos ZJ, Lipham WJ. Update on botulinum toxin and dermal fillers. Curr Opin Ophthalmol. 2010;21(5):387-395. https://doi.org/10.1097/ICU.0b013e32833ce7bc

2. Kattimani V, Tiwari RVC, Gufran K, et al. Botulinum Toxin Application in Facial Esthetics and Recent Treatment Indications (2013-2018). J Int Soc Prev Community Dent. 2019;9(2):99-105.

https://doi.org/10.4103/jispcd.JISPCD_430_18

3. Przylipiak M, Przylipiak J, Terlikowski R, et al. Improvements in the perception of facial attractiveness following surgical aesthetic treatment; study based on online before and after photos. J Cosmet Dermatol. 2019;18(1):296-300. https://doi.org/10.1111/jocd.12818

4. Kępa A. Peptydy biomimetyczne i czynniki wzrostu w kosmetologii i medycynie estetycznej Kosmetologia Estetyczna, 2013;2(2):105-111.

5. Lupo MP, Cole AL. Cosmeceutical peptides. Dermatol Ther. 2007;20(5):343-349.

https://doi.org/10.1111/j.1529-8019.2007.00148.x

6. Zhang L, Falla TJ. Cosmeceuticals and peptides. Clin Dermatol. 2009;27(5):485-494.

https://doi.org/10.1016/j.clindermatol.2009.05.013
7. Husein El Hadmed H, Castillo RF. Cosmeceuticals: peptides, proteins, and growth factors. J Cosmet Dermatol. 2016;15(4):514-519. https://doi.org/10.1111/jocd.12229

8. Aguilar-Toalá JE, Hernández-Mendoza A, González-Córdova AF, et al. Potential role of natural bioactive peptides for development of cosmeceutical skin products. Peptides. 2019;122:170170. https://doi.org/10.1016/j.peptides.2019.170170

9. Errante F, Ledwoń P, Latajka R, et al. Cosmeceutical Peptides in the Framework of Sustainable Wellness Economy. Front Chem. 2020;8:572923. https://doi.org/10.3389/fchem.2020.572923

10.Ledwoń P, Errante F, Papini AM, et al. Peptides as Active Ingredients: A Challenge for Cosmeceutical Industry. Chem Biodivers. 2021;18(2):e2000833. https://doi.org/10.1002/cbdv.202000833

11. Ramos-e-Silva M, Celem LR, Ramos-e-Silva S, Fucci-da-Costa AP. Anti-aging cosmetics: facts and controversies. Clin Dermatol. 2013;31(6):750-758.

https://doi.org/10.1016/j.clindermatol.2013.05.013

12.Schagen SK. Topical Peptide Treatments with Effective Anti-Aging Results. Cosmetics. 2017;4(2):16.

https://doi.org/10.3390/cosmetics4020016

13. Draelos ZD. The art and science of new advances in cosmeceuticals. Clin Plast Surg. 2011;38(3):397-407.

https://doi.org/10.1016/j.cps.2011.02.002

14. Vartanian AJ, Dayan SH. Complications of botulinum toxin A use in facial rejuvenation. Facial Plast Surg Clin North Am. 2005;13(1):1-10. https://doi.org/10.1016/j.fsc.2004.04.008

15. Blanes-Mira C, Clemente J, Jodas G, et al. A synthetic hexapeptide (Argireline) with antiwrinkle activity. Int J Cosmet Sci. 2002;24(5):303310. https://doi.org/10.1046/j.1467-2494.2002.00153.x

16.U.S. National Library of Medicine, Drug Information Portal Mobile Site. https://druginfo.nlm.nih.gov/drugportal/name/Acetyl+hexapeptide-3. Accessed 27.03.2021.

17.Lipotec. Argiline. An anti-aging peptide. https://wrinklesystem.com/ laboratorydata/argireline.pdf. Accessed 27.03.2021.

18. Chen YA, Scheller RH. SNARE-mediated membrane fusion. Nat ReV Mol Cell Biol. 2001;2(2):98-106. https://doi.org/10.1038/35052017

19. Argireline. https://www.lipotec.com/en/argireline/. Accessed 27.03.2021.

20. Ruiz MA, Clares B, Morales ME, Gallardo V. Evaluation of the anti-wrinkle efficacy of cosmetic formulations with an anti-aging peptide (Argireline ${ }^{\circledR}$ ). Ars Pharm. 2009;50(4):168-176. http://hdl.handle. net/10481/27392

21. ClinicalTrials.gov. https://clinicaltrials.gov/ct2/results?recrs=\&cond= \&term=argireline\&cntry=\&state $=\&$ city=\&dist. Accessed 26.03.2021.

22. Lungu C, Considine E, Zahir S, et al. Pilot study of topical acetyl hexapeptide-8 in the treatment for blepharospasm in patients receiving botulinum toxin therapy. Eur J Neurol. 2013;20(3):515-518. https://doi.org/10.1111/ene.12009

23. Grosicki M, Latacz G, Szopa A, et al. The study of cellular cytotoxicity of argireline - an anti-aging peptide. Acta Biochim Pol. 2014;61(1):29-32.

24. Bos JD, Meinardi MM. The 500 Dalton rule for the skin penetration of chemical compounds and drugs. Exp Dermatol. 2000;9(3):165-169. https://doi.org/10.1034/j.1600-0625.2000.009003165.x

25. Chen J, Bian J, Hantash BM, et al. Enhanced skin permeation of a novel peptide via structural modification, chemical enhancement, and microneedles. bioRxiv. 2020;10.07.312850.

https://doi.org/10.1101/2020.10.07.312850

26. Kraeling ME, Zhou W, Wang, Ogunsola OA. In vitro skin penetration of acetyl hexapeptide-8 from a cosmetic formulation. Cutan Ocul Toxicol. 2015;4(1):46-52. https://doi.org/10.3109/15569527.2014.894521

27. Krishnan G, Roberts MS, Grice J, et al. Iontophoretic skin permeation of peptides: an investigation into the influence of molecular properties, iontophoretic conditions and formulation parameters. Drug Deliv Transl Res. 2014;4(3):222-232.

https://doi.org/10.1007/s13346-013-0181

28. Hoppel M, Reznicek G, Kählig H, et al. Topical delivery of acetyl hexapeptide-8 from different emulsions: influence of emulsion composition and internal structure. Eur J Pharm Sci. 2015;68:27-35. https://doi.org/10.1016/j.ejps.2014.12

29. Ji M, Lee HS, Kim Y, et al. Method development for acetyl octapeptide-3 analysis by liquid chromatography-tandem mass spectrometry. J Anal Sci Technol. 2020;11(34):1-7. https://doi.org/10.1186/s40543-020-00232-8 
30. Kluczyk A, Ludwiczak J, Modzel M, et al. Argireline: Needle-Free Botox as Analytical Challenge. Chem Biodivers. 2021;18(3):e2000992. https://doi.org/10.1002/cbdv

31. Makowska J, Tesmar A, Wyrzykowski D, Chmurzyński L. Investigation of the Binding Properties of the Cosmetic Peptide Argireline and Its Derivatives Towards Copper(II) Ions. J Solution Chem. 2018;47:80-91. https://doi.org/10.1007/s10953-017-0705-9

32. Lim SH, Sun Y, Thiruvallur Madanagopal T, et al. Enhanced Skin Permeation of Anti-wrinkle Peptides via Molecular Modification [published correction appears in Sci Rep. 2018 Apr 20;8(1):6500]. Sci Rep. 2018;8(1):1596. https://doi.org/10.1038/s41598-017-18454-z

33.INCI Decoder. https://incidecoder.com/ingredients/acetyl-hexapeptide-8. Accessed 25.03.2021.

34. Cosmetic Ingredient Review. https://www.cir-safety.org/ingredients. Accessed 06.04.2021.

35.Drugbank. https://go.drugbank.com/drugs/DB11709. Accessed 12.02.2021.

36. Deciem. https://theordinary.deciem.com/pl/rdn-argireline-solution10pct-30ml.html. Accessed 30.03.2021.

37.U.S. National Library of Medicine, DailyMed. https://dailymed.nlm. nih.gov/dailymed/drugInfo.cfm?setid=da884734-c4fc-479f-887ee55ba6c8571e. Accessed 30.03.2021.

38. Ferrer Montiel AV, Fernández Ballester G, García Antón JM, et al. Compounds which Inhibit Neuronal Exocytosis. WO 2013153191A1.

39. Rozporządzenie Ministra Zdrowia z dnia 19 marca 2020 r. w sprawie metod oznaczeń próbek niezbędnych do kontroli bezpieczeństwa produktów kosmetycznych. Dziennik Ustaw Rzeczypospolitej Polskiej 2020 poz. 931.

40. Zhou W, Wang PG, Krynitsky AJ, Rader JI. Rapid and simultaneous determination of hexapeptides (Ac-EEMQRR-amide and $\mathrm{H}_{2} \mathrm{~N}$-EEMQRRamide) in anti-wrinkle cosmetics by hydrophilic interaction liquid chromatography-solid phase extraction preparation and hydrophilic interaction liquid chromatography with tandem mass spectrometry. J Chromatogr A. 2011;1218(44):7956-7963.

https://doi.org/10.1016/j.chroma.2011.08

41. Zhou W, Wang PG. Cosmetic bioanalysis using LC-MS: challenges and future outlook. Bioanalysis. 2014;6(4):437-440. https://doi.org/10.4155/bio.13

42.Stefanowicz P. Electrospray mass spectrometry and tandem mass spectrometry of the natural mixture of cyclic peptides from linseed. Eur J Mass Spectrom (Chichester). 2004;10(5):665-671. https://doi.org/10.1255/ejms

43. Kligman D. Cosmeceuticals. Dermatol Clin. 2000;18(4):609-615. https://doi.org/10.1016/s0733-8635(05)70211-4

44. Morrison I. Emulsion Technology Dispersions in liquids: suspensions, emulsions, and foams. ACS National Meeting, April 9-10, 2008, New Orleans. https://pdf4pro.com/view/dispersions-in-liquids-suspensionsemulsions-and-foams-421f57.html. Accessed 06.04.2021.
45. Califf RM, McCall J, Mark DB. Cosmetics, Regulations, and the Public Health: Understanding the Safety of Medical and Other Products. JAMA Intern Med. 2017;177(8):1080-1082.

https://doi.org/10.1001/jamainternmed.2017.2773

46. Kwa M, Welty LJ, Xu S. Adverse Events Reported to the US Food and Drug Administration for Cosmetics and Personal Care Products. JAMA Intern Med. 2017;177(8):1202-1204. https://doi.org/10.1001/jamainternmed.2017

47. Lim SH, Sun Y, Madanagopal TT, et al. enhanced skin permeation of anti-wrinkle peptides via molecular modification. Sci Report. 2018;25(8):1596. https://doi.org/10.1038/s41598-017-18454-z

48. Schagen SH. Topical peptide treatments with effective anti-aging results. Cosmetics. 2017;4(2):16. https://doi.org/10.3390/cosmetics4020016

49. Torosantucci R, Schöneich C, Jiskoot W. Oxidation of therapeutic proteins and peptides: structural and biological consequences. Pharm Res. 2014;31(3):541-553. https://doi.org/10.1007/s11095-013-1199

50. Davies MJ, Truscott RJ. Photo-oxidation of proteins and its role in cataractogenesis. J Photochem Photobiol B. 2001;63(1-3):114-125. https://doi.org/10.1016/s1011-1344(01)00208-1

51. Regl C, Wohlschlager T, Holzmann J, Huber CG. A Generic HPLC Method for Absolute Quantification of Oxidation in Monoclonal Antibodies and Fc-Fusion Proteins Using UV and MS Detection. Anal Chem. 2017;89(16):8391-8398.

https://doi.org/10.1021/acs.analchem.7b01755

52. Nabuchi Y, Fujiwara E, Ueno K, et al. Oxidation of recombinant human parathyroid hormone: effect of oxidized position on the biological activity. Pharm Res. 1995;12(12):2049-2052. https://doi.org/10.1023/a:1016281031373

53. Mozziconacci O, Ji JA, Wang YJ, Schöneich C. Metal-catalyzed oxidation of protein methionine residues in human parathyroid hormone (1-34): formation of homocysteine and a novel methionine-dependent hydrolysis reaction. Mol Pharm. 2013;10(2):739-755. https://doi.org/10.1021/mp300563m

54. Brühl L, Matthäus B, Scheipers A, Hofmann T. Bitter off-taste in stored cold-pressed linseed oil obtained from different varieties. Eur J Lipid Sci Technol. 2008;110(7):625-631. https://doi.org/10.1002/ejlt.200700314

55. Przybylski R, Eskin NAM. A comparative study on the effectiveness of nitrogen or carbon dioxide flushing in preventing oxidation during the heating of oil. J Am Oil Chem Soc. 1988;65(4):629. https://doi.org/10.1007/BF02540692

56. Grassi L, Cabrele C. Susceptibility of protein therapeutics to spontaneous chemical modifications by oxidation, cyclization, and elimination reactions. Amino Acids. 2019;51(10-12):1409-1431. https://doi.org/10.1007/s00726-019-02787-2 